\title{
PELATIHAN INOVASI PRODUK JAMUR TIRAM DI DESA GELAM KECAMATAN CIPOCOK JAYA
}

\author{
Listiawati ${ }^{1}$, Dewi Surani ${ }^{2}$, Sopiyah ${ }^{3}$ \\ 1,2,3Universitas Bina Bangsa \\ Email : listy234@gmail.com ${ }^{1}$, suranidewiahead@gmail.com $^{2}$, sopisopiyah13@gmail.com $^{3}$
}

\begin{abstract}
Abstrak
Desa Gelam (Kecamatan Cipocok Jaya) salah satu desa yang terletak di Kabupaten Serang. Desa Gelam memiliki kemampuan yang dapat dikembangkan dari hasil olahan Jamur Tiram yang menjadi ciri khusus. Desa Gelam mempunyai dua pengusaha Jamur Tiram belum diolah. Pelaksanaan penyuluhan dan pelatihan untuk ibu PKK dan Ibu Rumah Tangga (IRT) di Desa Gelam, khususnya tentang olahan produk pangan dalam rangka memberikan nilai tambah bagi Jamur Tiram. Penyuluhan dan pelatihan sudah dilaksanakan yaitu penyuluhan tentang pengolahan dan kebersihan dalam mengolah, merek dan pengemasan, pelatihan P-IRT dan membuat sertifikasi halal, kandungan produk dan jangka waktu produk, penggunaan alat dan kreasi pembuatan produk mitra tersebut. Harapan dari pelatihan ini bisa menjadi stimulus mitra untuk menciptakan produk yang bersaing dengan produk lain hingga bisa menaikan tingkat perekonomian desa Gelam. Pelaksanaan pengabdian masyarakat ini dievaluasi setiap bulannya dan dapat menjadi percontohan bagi para lbu PKK lainnya di Kabupaten Serang.
\end{abstract}

Kata Kunci : Pelatihan; Penyuluhan P-IRT; Produk olahan; Jamur Tiram

\section{Abstarct}

Gelam Village (Cipocok Jaya District) is one of the villages located in Serang Regency. Gelam Village has the ability that can be developed from processed oyster mushrooms which is a special characteristic. Gelam Village has two unprocessed Oyster Mushroom entrepreneurs. Implementation of counseling and training for PKK mothers and housewives in Gelam Village, especially regarding processed food products in order to provide added value to Oyster Mushrooms. Counseling and training have been carried out, namely counseling on processing and cleanliness in processing, branding and packaging, P-IRT training and making halal certification, product content and product duration, use of tools and creation of partner products. The hope of this training can be a stimulus for partners to create products that compete with other products so that they can raise the level of the Gelam village economy. The implementation of this community service is evaluated every month and can be a pilot for other PKK mothers in Serang Regency.

Keywords : Training; counseling P-IRT; processed products; oyster mushrooms

\section{PENDAHULUAN}

Jamur tiram (Pleurotus ostreatus) merupakan jamur kayu yang biasa dikuonsumsi. Jamur yang banyak dikembangkan oleh para petani di Indonesia. pengembangbiakan jamur menggunakan teknologi yang mudah karena itu bisa dikembangkan bagi yang masih belum berpengalaman. Pengembangbiakan jamur dapat dikelompokkan sebagai pengembangbiakan yang aman karena bahan yang digunakan untuk pengembambiakan jamur bisa dengan kulit gabah. Pengembangbiakannya jamur adalah bentuk yang pemanfaatan bahan lokal, tanpa perlu membeli dari Luar Negeri. Pengembangbiakan jamur salah satu bentuk menganekaragamkan makanan sehingga bisa digunakan untuk membuat 
kreasi olahan pangan. Pengembangbiakan jamur tiram bisa memberi kesempatan penghasilan bagi warga setempat (Djarwanto \& Suprapti, 2010). Jamur tiram rasanya nikmat hampir sama seperti daging ayam, jamur tiram juga disenangi oleh berbagai macam usia dikarenakan memiliki kegunaan bagi tubuh. Jamur mempunyai kandungan protein yang tinggi sekitar $17,5 \%$ sampai $27 \%$ dengan lemak yang rendah 1,6-8\% dan kandungan serat pangan yang tinggi $8-11,5 \%$ sehingga bisa diolah menjadi panganan bergizi. kandungan karbohidrat yang besar sebagai tedapat dalam jamur tiram. Protein adalah zat yang dibutuhkan manusia untuk mendukung pertumbuhan. Pada protein ada penghasil energi dan pengatur tubuh (Muchtadi , 2010). Protein memiliki manfaat untuk biokatalisator enzim pada proses kimia. Sumber makanan yang mengandung kaya akan protein yang yang biasa dikonsumsi di indonesia adalah kedelai yang diolah menjadi tempe maupun tahu (Ginting, Herlina, \& Tyasmoro, 2013). Tetapi dikarenakan harga kedelai yang melonjak sehingga masyarakat perlu makanan alternatif seperti dari olahan Jamur Tiram

Kandungan yang dimiliki oleh jamur Tiram yaitu proteinnya, bisa dipilih untuk dijadikan panganan yang mengandung protein untuk pemenuhan kebutuhan gizi. Menurut (Parjimo dan Andoko,2007), jamur tiram memiliki kandungan protein dalam $100 \mathrm{~g}$ yaitu $27 \%$ tetapi kedelai tempe memiliki protein 18,3\% dalam 100g. (Muchtadi, 2010), selain itu jamur tiram memiliki rasa yang mirip seperti daging. Jamur tiram putih dikategorikan merupakan bahan mentah yang dapat dimakan dan aman jadi bisa dikonsumsi (Winarno, 2004),. Jamur Tiram selain aman untuk dikonkumsi merupakan makanan yang mengandung nutrisi. Kandungan nutrisi yang terdapat pada Jamur Tiram adalah protein, karbohidrat, lemak, serat pangan, thiamin, riboflavin, niacin, dan kalsium, serta vitamin dan mineral. Kandungan serat yang terdapat dalam jamur tiram sekitar $7,4-24,6 \%$ jadi bisa dikonsumsi bagi yang berdiet. Inovasi dalam pembuatan olahan makanan dari jamur tiram bermanfaat bagi petani jamur dan pengusaha jamur sehingga dapat menaikkan nilai tambah jamur. Jamur tiram (Pleurotus ostreatus) yang biasa dibudidayakan serta dikonsumsi dikarenakan rasanya nikmat, memiliki kandungan gizi dan bisa dijadikan sebagai obat. Dari penelitian yag pernah dilakukan jamur tiram memiliki kandungan antidiabetes, antibakteri, antikolesterol, antiartritik, antioksidan, antikanker, bagus untuk kesehatan mata dan antivirus. Jamur tiram memiliki senyawa aktif polisakarida disebut beta-glukan. Salah satu usaha masyarakat di Desa Gelam. Para Ibu Rumah Tangga bisa diajak kerjasama serta mempunyai keinginan agar bisa mengikuti pelatihan yang dapat meningkatkan perekonomian mereka melalui cara pengolahan jamur tiram. Produk yang diciptakan beragam, seperti Abon, Kaldu, Sambal, Dimsum dan nugget jamur tiram. Program implementasi Ipteks Bagi Masyarakat melalui pendampingan memiliki tujuan agar bisa menaikkan produksi masyarakat setempat, terutama jamur tiram yang ada di Desa Gelam, Kecamatan Cipocok Jaya Kabupaten Serang. Kegiatan ini dilakukan untuk membuat olahan makanan seperti produk Abon, Kaldu, Sambal, Dimsum dan nugget jamur tiram, pelatihan kebersihan dalam memproduksi, pelatihan P-IRT dan sertifikasi halal, analisis kimia gizi dan masa kadaluarsa (expire date), transfer teknologi peralatan, cara membuat label dan pengemasan produk (Winarno \& Surono, 2002). Keinginan yang diharapkan oleh kegiatan ini untuk info dan transfer yang 
diperoleh dari pengolahan makanan dan pengemasan agar dapat meningkatkan perekonomian setempat. Tujuan dari kegiatan ini adalah yang pertama, penyadaran para IRT mengenai pentingnya aspek sanitasi dan hygiene dalam mengolah atau memproduksi pangan. Kedua, peningkatan pengetahuan IRT tentang metode olahan makanan mentah menggunakan metode sesuai hingga bisa menaikkan mutu dan efisiensi makanan mentah untuk dijadikan Abon, Kaldu, Sambal, Dimsum dan nugget jamur tiram untuk menaikan perekonomian setempat. Ketiga, meningkatkan imu dan skill masyarakat Desa Gelam dengan pelatihan kewirausahaan pemasaran dan pengemasan. Keempat, menaikkan kesejahteraan IRT melalui peningkatan pendapatan dari pembuatan olahan Abon, Kaldu, Sambal, Dimsum dan nugget jamur tiram. Kelima, menciptakan pekerjaan.

\section{METODE}

Metode pelaksanaan yang digunakan yaitu metode partisipatif dan kooperatif. Pendekatan dilakukan supaya masyarakat bisa bekerjasama dan berdiskusi dengan sasaran sedangkan tim pelaksana memiliki peran sebagai fasilitator selama proses diskusi. Susunan kegiatan yang dilakukan saat kegiatan berlangsung disusun secara bertahap yang meliputi :
a) Survey awal dan pengenalan masalahan;
b) melakukan Diskusi;
c) melakukan pelatihan;
d) melakukan pembinaan; dan
e) melakukan Monitoring dan Evaluasi.

\section{HASIL DAN PEMBAHASAN}

Hasil budidaya jamur tiram dari Desa Gelam. Hasil pencapaian dari pelaksanaan kegiatan Pelatihan adalah :

(1) Meningkatkan ilmu para Ibu Rumah Tangga ikut pelatihan tentang metode pengolahan Abon, Kaldu, Sambal, Dimsum dan nugget jamur tiram dengan cara tepat guna hingga dapat menaikkan mutu dan efisiensi pada olahan bahan mentah menjadi produk makanan untuk menaikan tingkat ekonomi mereka. Pengolahan Abon, Kaldu, Sambal, Dimsum dan nugget jamur tiram menggunakan sumber daya yang ada.

(2) Pengalihan metode dan ilmu tentang penerapan metode yang tepat dalam proses pembuatan Abon, Kaldu, Sambal, Dimsum dan nugget jamur tiram, agar memperoleh hasil yang bergizi dan sehat

(3) IImu yang disampaikan yaitu cara pemilihan bahan, pencucian, sterilisasi bahan kemasan, mengolah bahan sehingga jadi makanan olahan, hingga pengemasan produk , perizinan P-IRT dan sertifikasi halal MUI. 
(4) Pelatihan merupakan sarana dan bahan pembelajaran dengan melibatkan penuh. Dalam pelatihan ini, para Ibu Rumah Tangga memperoleh pengetahuan teknik pengolahan Abon, Kaldu, Sambal, Dimsum dan nugget jamur tiram.

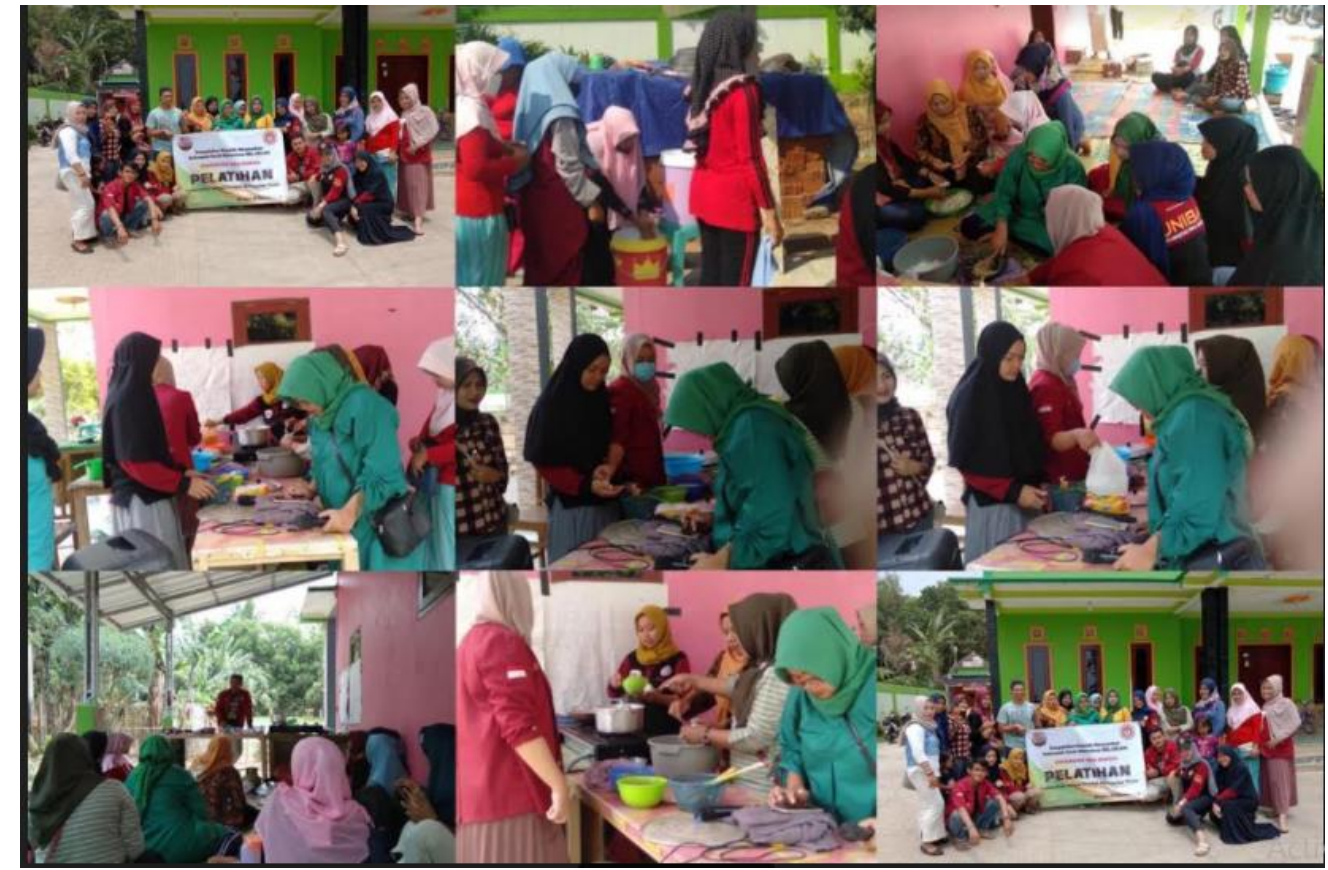

Gambar 1. Kegiatan Pelatihan Olahan makanan dari Jamur Tiram

Sasaran yang telah dilakukan, yaitu :

(1) Dengan Pelatihan dan bertukar pikiran, para Ibu Rumah Tangga sudah sadar dan paham tentang menjaga kehigienisan untuk memproduksi Abon, Kaldu, Sambal, Dimsum dan nugget jamur tiram.

(2) Bertambahnya pengetahuan Para Ibu Rumah Tangga tentang metode mengolah jamur tiram menggunakan metode yang sesuai jadi bisa menaikkan mutu dan efisiensi olahan jamur tiram menjadi produk Abon, Kaldu, Sambal, Dimsum dan nugget jamur tiram untuk menaikkan perekonomian warga setempat.

(3) Nilai tambah dari sisi ilmu dan skill Para Ibu Rumah Tangga untuk berwirausaha

(4) Para ibu Rumah Tangga mulai memproduksi produk Abon, Kaldu, Sambal, Dimsum dan nugget jamur tiram yang dikemas dengan kualitas yang tinggi.

(5) menciptakan pekerjaan baru sebagai sumber penghasilan tambahan dari olahan jamur tiram.

Produk Usaha aneka olahan jamur yang dihasilkan adalah makanan frozen. Kita sudah sering melihat makanan frozen beredar dipasaran. Supaya dapat dibedakan olahan 
jamur tiram dengan makanan frozen yang sudah ada, kami berikan variasi. Variasi olahan jamur tiram, diantaranya :

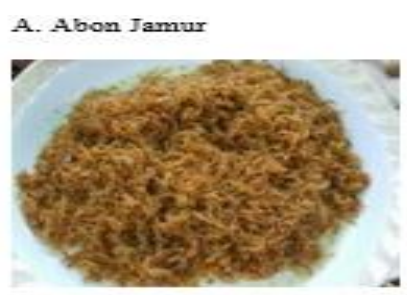

B. Kaldu Jamur

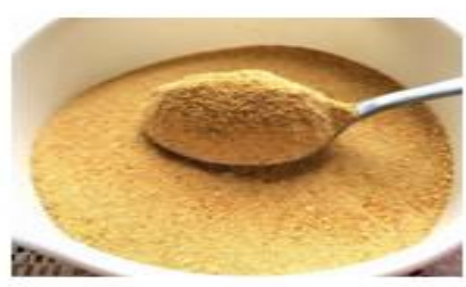

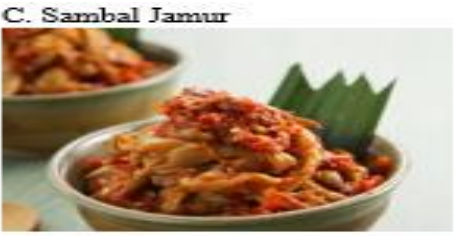

D. Nauget Jamur
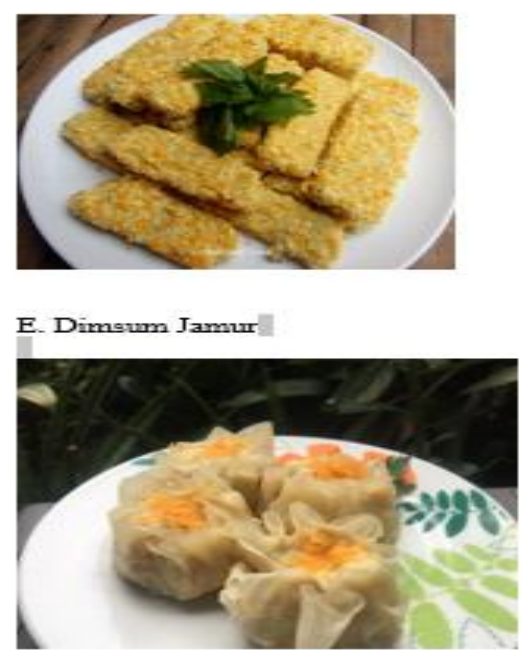

Gambar 2. Produk Olahan dari Jamur Tiram

\section{KESIMPULAN}

Pertama, sudah ada kesadaran dari warga tentang memanfaatkan jamur tiram sebagai produk lokal menjadi produk khas dari Desa Gelam Kecamatan Cipocok Jaya Kabupaten Serang. Kedua, adanya perubahan metode yang digunakan dalam pembuatan, pengemasan dan cara memasarkan oleh Para Ibu Rumah Tangga di Desa Gelam, sehingga mampu melakukan proses produksi secara mandiri. Dan ketiga, Para lbu Rumah tangga sangat antusias memproduksi produk Abon, Kaldu, Sambal, Dimsum dan nugget jamur tiram untuk peningkatan ekonomi secara mandiri. 


\section{DAFTAR PUSTAKA}

Djarwanto, D., \& Suprapti, S. (2010). Pengaruh Sumber Bibit Terhadap Pertumbuhan Jamur Tiram. Jurnal Penelitian Hasil Hutan, Vol. 28, pp. 156-168. https://doi.org/10.20886/jphh.2010.28.2.156-168

Ginting, A. R., Herlina, N., \& Tyasmoro, S. Y. (2013). Studi Pertumbuhan Dan Produksi Jamur Tiram Putih (Pleorotus ostreatus) Pada Media Tumbuh Gergaji Kayu Sengon Dan Bagas Tebu. Jurnal Produksi Tanaman, 1(2), 17-24.

Djarwanto, Suprapti S, Gandjar I. 1994. Manfaat Jamur Tiram dalam Upaya Peningkatan Nilai Ekonomi Limbah Kayu. Lokakarya Nasional Mikrobiologi Lingkungan, LIPI. Bogor.

Hariyadi, P., 2008. Pendugaan dan Pengendalian Masa Kadaluarsa (Shelf Life) Produk Pangan. Departemen Ilmu dan Teknologi Pangan -IPB. Bogor.

Muchtadi D. 2010. Teknik Evaluasi Nilai Gizi Protein. Penerbit Alfabeta, Bandung.

Parjimo, Andoko A. 2007. Budi Daya Jamur. Agromedia Pustaka. Jakarta.

Winarno, F.G dan Surono. 2002. GMP: Cara Pengolahan Pangan yang Baik. Mbrio Press, Bogor.

Winarno, F.G. 2004. Kimia Pangan dan Gizi. Gramedia Pustaka Utama, Jakarta.

Yananto Mihadi Putra, \& Abdul Ghani. (2020). PENDAMPINGAN PENERAPAN TATA KELOLA USAHA DAN PEMBUKUAN BERBASIS SAK-EMKM PADA SEKTOR USAHA KECIL DI KELURAHAN MERUYA SELATAN. Jurnal Abdimas Bina Bangsa, 1(1), 119-127. doi:10.46306/jabb.v1i1.47

Widayanto, M. T., Pujiastuti, A., Yatiningrum, A., Tumini, \& Rahma Dhany, U. (2020). SOSIALISASI PENTINGNYA LEGALITAS USAHA DAN PENJUALAN ONLINE UNTUK PENGEMBANGAN USAHA MIKRO KECIL DAN MENENGAH. Jurnal Abdimas Bina Bangsa, 1(2), 240-246. doi:10.46306/jabb.v1i2.37 